\title{
Selected works by Margaret Harkness
}

\section{Fiction (including experimental writing)}

John Law (1887). A City Girl: A Realistic Story. London: Vizetelly \& Co. Reprinted (1890). London: Authors' Co-operative Publishing Co. John Law (1888). Out of Work. Swan Sonnenschein \& Co. John Law (1888). 'Captain Lobe: A Story of the East End'. British Weekly, 6 April-14 December.

Reprinted (1889; 1915; 1925). Captain Lobe: A Story of the Salvation Army. London: Hodder \& Stoughton.

Reprinted (1891; 1893). In Darkest London: A New and Popular Edition of Captain Lobe. Bellamy Library 8. London: W. Reeves. With an introduction by William Booth.

John Law (1888). 'The Gospel of Getting On. (To Olive Schreiner)'. To-day: A Monthly Magazine of Scientific Socialism.

John Law (1889). 'A Pantomime Child'. British Weekly: A Journal of Social and Christian Progress, 27 December.

John Law (1890). A Manchester Shirtmaker: A Realistic Story of To-day. London: Authors' Co-operative Publishing Co.

John Law (1890). 'His First Day's Wages'. Pall Mall Gazette, 13 September.

Reprinted (1890). Sydney Mail, 13 December.

John Law (1890). 'Little Tim's Christmas'. Pall Mall Gazette, 24 December.

Reprinted (1891). Daily Telegraph Supplement, 16 May. John Law (1891-92). 'Roses and Crucifix'. Woman's Herald, 5 December-27 February.

John Law (1893-94). 'Connie'. Labour Elector, June-January. John Law (1897). 'Called to the Bar: A Coolgardie Novel', Western Mail 30 July-24 September.

John Law (1900). 'Ideals'. Southern Cross, 20 April. 
John Law (1903). 'Two Christmases'. West Australian, 25 December. John Law (1904). 'A Leap Year Story'. West Australian, 27 February. John Law (1904). 'A Bush Drama. An Irony of Fate'. West Australian, 13 August.

Reprinted (1904). Evening Star, 16 August.

John Law (1905). George Eastmont: Wanderer. London: Burns \& Oates. John Law (1913; 1915). The Horoscope. Calcutta, Simla, and London: Thacker, Spink \& Co.

John Law (1921). A Curate's Promise: A Story of Three Weeks. London: Hodder \& Stoughton.

\section{Non-fiction (including journalism)}

Margaret E. Harkness (1881). 'Women as Civil Servants'. Nineteenth Century, September.

Margaret E. Harkness (1882). 'Railway Labour'. Nineteenth Century, November.

Margaret E. Harkness (1883). 'The Municipality of London'. National Review, May, September.

Margaret Elise Harkness (1883). Assyrian Life and History. London: Religious Tract Society. With an introduction by R. Stuart Poole.

M. E. H. (1884). 'Hospital Nurses'. Leisure Hour: An Illustrated Magazine for Home Reading (33). 152-54.

Margaret Elise Harkness (1884). Egyptian Life and History according to the Monuments. London: Religious Tract Society.

Margaret E. Harkness (1888). 'Girl Labour in the City'. Justice, 3 March. Margaret E. Harkness (1888). 'Salvationists and Socialists'. Justice, 24 March.

Unsigned, ed. by Harkness (1888). 'Tempted London: Young Women'. British Weekly, 27 April-28 December.

Reprinted: “"British Weekly" Commissioners', ed. by 'the Author of "Out of Work," etc.' (1889). Toilers in London, or: Inquiries Concerning Female Labour in the Metropolis. London: Hodder \& Stoughton.

Margaret E. Harkness (1888). 'Home Industries'. Justice, 28 August. John Law (1889). 'A Reflection'. Justice, 20 April.

Anon. (1889). 'Life in Lancashire'. British Weekly, 10 May-7 June[?]. John Law (1889). 'To the Editor of the Daily Nerws'. Daily Nerws, 23 August.

John Law (1889). 'The Strike of the London Dock Labourers'. Labour Elector, 31 August. 
John Law (1889). “The Dockers' “Tanner”'. British Weekly, 6 September. John Law (1889). 'The Strike Continues'. British Weekly, 13 September. John Law (1889). 'The Loafer. What Shall We Do with Him'. Labour Elector, 21 September.

Margaret G. [sic] Harkness (1890). 'The Future of the Labour Party'. Pall Mall Gazette, 7 March.

Reprinted (1890). Labour Elector, 15 March.

Unsigned (1890). 'The Emperor and the Socialists. An Interview with Herr Bebel'. Pall Mall Gazette, 23 June.

Unsigned (1890). 'The Socialist Movement in Austria. An Interview with Dr. Victor Adler'. Pall Mall Gazette, 28 August.

J. L. (1890). 'The Loafer in Germany'. Pall Mall Gazette, 9 September.

J. L. (1890). 'The Viennese Pauper'. Pall Mall Gazette, 18 September. John Law (1890). “'Salvation” v. Socialism: In Praise of General Booth'. Pall Mall Gazette, 21 October.

'One who Knows "John Law"' (1890). “Salvation” and Socialism'. Pall Mall Gazette, 29 October.

J. L. (1891). 'Labour Leaders'. Pall Mall Gazette, 10 January-18 February [4 parts].

John Law (1891). 'Princess Christian and "Captain Lobe"'. Pall Mall Gazette, 2 March.

John Law (1891). 'John Law's Religion'. Pall Mall Gazette, 1 September. John Law (1891). 'A Year of My Life'. Nerw Review, October.

John Law (1892). 'The Cardinal as I Knew Him'. Pall Mall Gazette, 18 January.

John Law (1892). 'Olive Schreiner'. Novel Review, May.

John Law (1893). 'The Children of the Unemployed'. New Review, February.

John Law (1894). 'A Week on a Labour Settlement'. Fortnightly Review, 1 August.

John Law (1899). Imperial Credit. Adelaide: Privately published, printed by Vardon and Pritchard.

John Law (1903-4). 'The Passing Hour'. West Australian, 21 March-20 August [61 articles].

John Law (1904-5). 'London Letter'. West Australian, 3 November-14 March [6 articles].

John Law (1905). 'The Labour Colony in Essex', Western Mail, 10 February.

John Law (1905). 'Ceylon as a Holiday Resort for Australians'. West Australian, 9 June-8 August [9 parts]. 
John Law (1906). 'Impressions of India'. West Australian, 10 March. John Law (1906). 'Buddhism'. West Australian, 17 March-19 April [5 parts].

John Law (1906). 'The Theosophical Headquarters at Adyar'. West Australian, 9 July.

John Law (1907). 'The Indian National Congress'. West Australian, 5 February.

John Law (1907). 'The Theosophical Convention at Adyar'. West Australian, 16 February.

John Law (1907). 'A Letter from India'. West Australian, 20 March-27 May [2 parts].

John Law (1909). Glimpses of Hidden India. Calcutta: Thacker, Spink \& Co.

John Law (1912). Indian Snapshots. Calcutta: Thacker, Spink \& Co. John Law (1914). Modern Hyderabad. Calcutta: Thacker, Spink \& Co. 